DOE/NV/10845-53

UC-703

\title{
FATE AND TRANSPORT PROCESSES CONTROLLING THE MIGRATION OF HAZARDOUS AND RADIOACTIVE MATERIALS FROM THE AREA 5 RADIOACTIVE WASTE MANAGEMENT SITE (RWMS)
}

by

Rocio Estrella

OCTOBER 1994

Publication \#45134

DLGTRIBUTION OF THIS DOCUMENT IS UNLIMITED $\checkmark R$ 
This report was prepared as an account of work sponsored by the United States Government. Neither the United States nor the United States Department of Energy, nor any of their employees, makes any warranty, express or implied, or assumes any legal liability or responsibility for the accuracy, completeness or usefulness of any information, apparatus, product or process disclosed, or represents that its use would not infringe privately owned rights. Reference herein to any specific commercial product, process, or service by trade name, mark, manufacturer, or otherwise, does not necessarily constitute or imply its endorsement, recommendation, or favoring by the United States Government or any agency thereof. The views and opinions of authors expressed herein do not necessarily state or reflect those of the United States Government or any agency thereof.

This report has been reproduced directly from the best available copy.

Available to DOE and DOE contractors from the Office of Scientific and Technical Information, P.O. Box 62, Oak Ridge, TN 37831; prices available from (615) 576-8401.

Available to the public from the National Technical Information Service, U.S. Department of Commerce, 5285 Port Royal Rd., Springfield, VA 22161. 


\section{DISCLAIMER}

Portions of this document may be illegible in electronic image products. Images are produced from the best available original document. 


\title{
FATE AND TRANSPORT PROCESSES CONTROLLING THE MIGRATION OF HAZARDOUS AND RADIOACTIVE MATERIALS FROM THE AREA 5 RADIOACTIVE WASTE MANAGEMENT SITE (RWMS)
}

\author{
by \\ Rocio Estrella \\ Water Resources Center \\ Desert Research Institute \\ University and Community College System of Nevada
}

Publication No. 45134

prepared for

Nevada Operations Office

U.S. Department of Energy

Las Vegas, Nevada

October 1994

The work upon which this report is based was supported by the U.S. Department of Energy under Contract \#DE-AC08-90NV10845. 


\section{CONTENTS}

TABLES $\ldots \ldots \ldots \ldots \ldots \ldots \ldots \ldots \ldots \ldots \ldots \ldots \ldots \ldots \ldots \ldots \ldots \ldots \ldots \ldots \ldots \ldots$

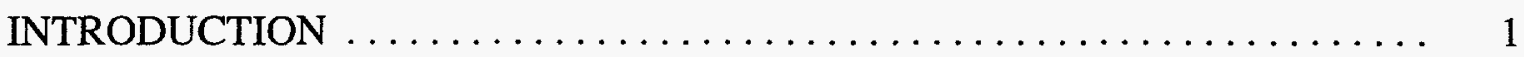

SORPTION PROCESSES $\ldots \ldots \ldots \ldots \ldots \ldots \ldots \ldots \ldots \ldots \ldots \ldots \ldots \ldots$

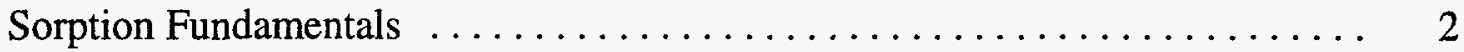

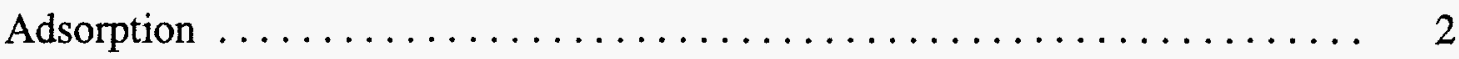

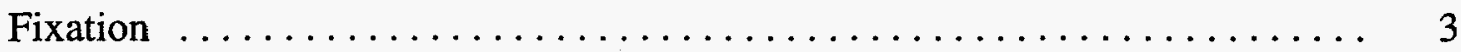

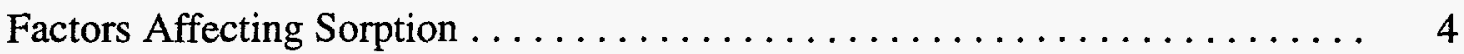

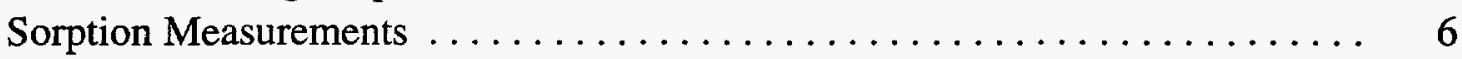

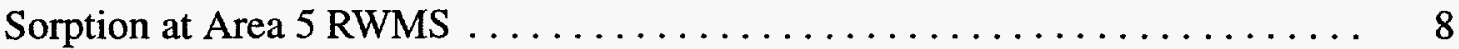

TRANSFORMATION PROCESSES $\ldots \ldots \ldots \ldots \ldots \ldots \ldots \ldots \ldots \ldots \ldots \ldots$

Chemical Transformations $\ldots \ldots \ldots \ldots \ldots \ldots \ldots \ldots \ldots \ldots \ldots \ldots \ldots \ldots \ldots \ldots$

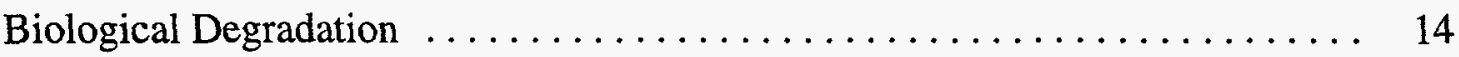

Transformation Processes at Area 5 RWMS $\ldots \ldots \ldots \ldots \ldots \ldots \ldots \ldots \ldots$

TRANSPORT PROCESSES $\ldots \ldots \ldots \ldots \ldots \ldots \ldots \ldots \ldots \ldots \ldots \ldots \ldots \ldots$

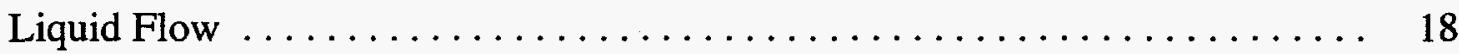

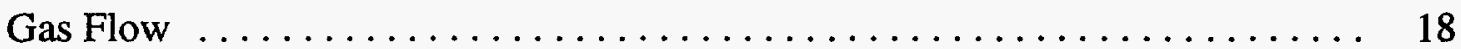

Diffusional Soil-Gas Transport $\ldots \ldots \ldots \ldots \ldots \ldots \ldots \ldots \ldots \ldots \ldots \ldots$

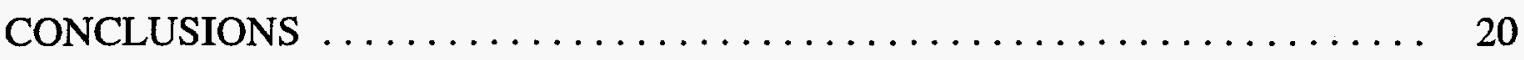

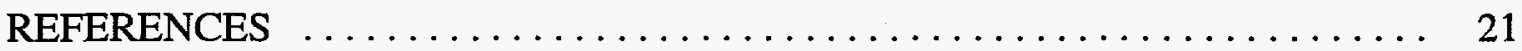

\section{TABLES}

1. Summary of Soil Properties Related to Sorption at the Area 5 RWMS of the Nevada Test Site and Vicinity.

2. Partition Coefficients (K) Reported by Steinberg and Kreamer (1993) for VOCs Using the Silt and Clay Size Fraction at $1.65 \%$

Gravimetric Water Content.

3. Summary of Sorption Coefficients $(\mathrm{Kd})$ from Soils at the Area 5 RWMS of the Nevada Test Site and Vicinity. 


\section{INTRODUCTION}

Desert vadose zones have been considered as suitable environments for the safe and long-term isolation of hazardous wastes. Low precipitation, high evapotranspiration and thick unsaturated alluvial deposits commonly found in deserts make them attractive as waste disposal sites (Gee et al., 1994).

Fate and transport processes in arid zones, however, have not been extensively studied. Only recently has there been this focused need to understand these processes in desert soils. Thus, little information is available regarding these processes in arid sites. The fate and transport of any contaminant in the subsurface is ultimately determined by the operating retention and transformation processes in the system and the end result of the interactions among them. Retention (sorption) and transformation are the two major processes that affect the amount of a contaminant present and available for transport. Retention processes do not affect the total amount of a contaminant in the soil system, but rather decrease or eliminate the amount available for transport at a given point in time. Sorption reactions retard the contaminant migration. The bulk is still available for transport, but at a rate which is slower than the fluid movement. Permanent binding of solute by the sorbent is also possible. Transformation processes can actually reduce or totally eliminate the amount of contaminants present and available for transport (Cheng and Koskinen, 1986). However, transformation processes can also form contaminants from non-toxic precursors, make contaminants more available for migration and even release bound contaminants. These processes and their interactions are controlled by the nature of the hazardous waste, the properties of the porous media and the geochemical and environmental conditions (temperature, moisture and vegetation).

The present study summarizes the available data and investigates the fate and transport processes that govern the migration of contaminants from the Radioactive Waste Management Site (RWMS) in Area 5 of the Nevada Test Site (NTS). While the site is currently used only for low-level radioactive waste disposal, past practices have included burial of material now considered hazardous. The purpose of this effort is to define data availability and to better direct future data collection activities. An overview of relevant sorption processes is given first, followed by a discussion of results obtained to date. Fundamentals of chemical and biological transformation processes are discussed subsequently, followed by a discussion of relevant results. 


\section{SORPTION PROCESSES}

Sorption processes involve partitioning of a chemical species among the different available phases (solid, liquid, or gas) in the subsurface. Sorption processes are attenuation mechanisms that do not affect the total amount of the chemical species present in the soil system, but rather decrease or eliminate the amount available for transport at a given point in time.

\section{Sorption Fundamentals}

Sorption processes generally involve all phases present in the subsurface system as well as the interfaces between the phases. The solute that undergoes sorption is called "sorbate." The sorbing phase is the "sorbent." The primary phase from which sorption occurs is commonly termed the "solution" or "solvent" (Weber et al., 1991). Sorption processes are physicochemical reactions that are influenced by both intermolecular forces and the chemical conditions of the porous media. Sorption decreases chemical mobility by removing a chemical species from the solution or vapor phases and depositing it onto the solid phase. There are two broad categories of sorption reactions, namely adsorption and fixation, differing only in the degree of sorbate-sorbent interaction.

\section{Adsorption}

Adsorption refers to the bonding of a solute in solution or vapor phases to adsorption sites on the soil solid surfaces (soil mineral surfaces and/or organic matter surfaces) or interfaces between the solution and the adsorbent. There are different types of bonding mechanisms that can operate in adsorption.

Ionic bonds occur between an anionic or cationic species and a positive or negative electric charge at the surface of the adsorbent (Jury, 1986). Ion exchange is the dominant form of adsorption for trace metals in soils where a substantial part of the surface area is associated with smectite (expanding) clays, under conditions of low ionic strength. In that case, the permanent (negative) structural charge in the clay interlayer region will attract cationic species. Soil organic matter can also be responsible for the accumulation of cationic species at soil surfaces. The cation exchange capacity (CEC) of a soil is a measure of the quantity of cations that can be held or exchanged per unit weight of soil and it is extremely site specific. Although soils also have particles that contain positive surface charges (e.g., iron, manganese and aluminum hydrous oxides, and the edges of aluminosilicate clay minerals) responsible for accumulating anions, generally the anion exchange capacity (AEC) of a soil is relatively smaller than the adsorption capacity of cations (Dragun, 1988). Adsorption by ion exchange is a function of the ionic charge, size and activity of the sorbing ions. Ions with a greater charge are adsorbed more strongly (e.g., soils tend to adsorb calcium ions $\left(\mathrm{Ca}^{2+}\right)$ more effectively than ammonium $\left(\mathrm{NH}_{4}^{+}\right)$or sodium $\left(\mathrm{Na}^{+}\right)$ions). Smaller ions are generally held tighter because their size allows them to approach closer to the charged surface. The relative affinity of the soil for a particular ion can be overcome by a change in concentration of a less favorable ion. If an ion is present at high activity, it may replace ions low in concentration regardless of their size or charge, provided the two competing ions bind to the soil surface via the same mechanisms (e.g., ion exchange) (Devinny et al., 1990). The activity of an ion $\left(a_{i}\right)$ or solute species $i$ is equal to the molality of that solute species $\left(\mathrm{m}_{\mathrm{i}}\right)$ times the activity coefficient $\left(\gamma_{\mathrm{i}}\right)$. The activity of an ion refers 
to the thermodynamically effective concentration and it is conceptually considered to be that portion of $\mathrm{m}_{\mathrm{i}}$ that actually participates in thermodynamic processes (Freeze and Cherry, 1979).

Hydrogen bonds occur when a hydrogen atom serves as a bridge between two electronegative atoms (Dragun, 1988). Although hydrogen bonds are weak electrostatic bonds, summed over many atoms, these bonds can strongly bond adjacent structures (e.g., molecules) (Bohn et al., 1985). Hydrogen bonds are mainly associated with $-\mathrm{NH}$ or $-\mathrm{OH}$ groups and $\mathrm{N}$ and $\mathrm{O}$ atoms. Therefore, most organic molecules in soils are potentially able to establish hydrogen bonds (Jury, 1986).

Van der Waals bonds are weak electrostatic bonds that occur between residual charges on molecules. These bonds are caused by the instantaneous dipoles established when electrons fluctuate in their orbitals. These interactions are important only at short sorbate-sorbent distances. Van der Waals forces decay rapidly with distance, thus their contribution to adsorption is most significant for those sorbate molecules that are closest to the adsorbent or whose shape and/or size enable close contact with adsorbing surfaces. The size and shape of the molecule determines the strength of this type of bond. Small spherically shaped molecules are better retained by van der Waals forces than bulky and irregularly shaped molecules (Bailey and White, 1970). If a solute molecule has a permanent charge, a strong binding interaction of ion exchange will operate. However, neutral non-polar molecules may bind by van der Waals interactions or other weak bonding mechanisms (Jury, 1986).

Charge-dipole bonds and dipole-dipole bonds are involved between polar organic molecules and electrically charged or polar adsorbing surfaces (Jury, 1986). This type of intermolecular force has not been studied extensively in soils, however, it is known that as a result of these types of bonds, polar molecules usually exhibit a lower vapor pressure and volatility (Dragun, 1988).

\section{Fixation}

Fixation refers to soil chemical reactions that immobilize an element at the soil mineral surfaces or within the structure of the soil minerals or organic matrix. Fixation involves three types of reactions: chemisorption, absorption and precipitation. Chemisorption and absorption are not considered to be extensively occurring reactions (Dragun, 1988). Precipitation, however, is an extremely important reaction and has a major effect on the ultimate fate of an element in soils.

Chemisorption refers to the formation of covalent (shared electron pair) chemical bond between the sorbate and the sorbent. These bonds are very strong, requiring high energy input to break them (about $100 \mathrm{kcal} / \mathrm{mol}$ ). When solute molecules establish a chemical bond with the sorbent, they become essentially part of the surface and are irreversibly adsorbed (Deviny et al., 1990). Chemisorption is rarely seen because it is an energy intensive process, often occurring only at high temperatures (Adamson, 1982).

Absorption refers to the irreversible solute interpenetration into the sorbent by solid-state diffusion or diffusive mass transfer. In absorption, the solute is immobilized within the structure of the sorbent (soil minerals or organic matrix). There are wide variations in the ease by which ions reach the exchange sites, and often, days or weeks are required for an ion to diffuse into the interior of the layered structure of a clay mineral or interior of the organic matrix. The rate of solid diffusion 
depends on charge and size similarities between the diffusing cation and the major cation of the mineral lattice. In some instances, the affinity of ions like potassium $\left(\mathrm{K}^{+}\right)$and cesium $\left(\mathrm{Cs}^{+}\right)$for the exchange sites is so great that the site is denied to other ions. $\mathrm{Cs}^{+}$has been shown to cause a collapse of the lattice of vermiculite such that previously sorbed calcium $\left(\mathrm{Ca}^{++}\right)$and strontium $\left(\mathrm{Sr}^{++}\right)$may be trapped (ion fixation) and the exchange capacity reduced by over 80 percent (Kaufman, 1963).

Precipitation results when a sufficiently high accumulation of solute occurs (saturation concentration) at the solute-sorbent interface, resulting in the formation of a new phase (precipitate) (Weber et al., 1991). Precipitation is a thermodynamic equilibrium reaction controlled by factors such as the concentration of the chemical species, $\mathrm{pH}$ and redox potential of the soil system, and solubility constants. If these conditions change, the precipitate may dissolve into the soil solution (dissolution) (Hutchinson and Ellison, 1992).

\section{Factors Affecting Sorption}

The extent and nature of the bonding mechanisms in adsorption are a function of the specific soil parameters (e.g., soil mineralogy, specific surface area, organic matter content, $\mathrm{pH}$, and electrical conductivity of the soil system), the chemical properties of the solute (e.g., molecular structure, size and shape) and the environmental conditions ( e.g., temperature and moisture content).

Specific soil parameters that are known to dramatically affect the extent of sorption/desorption are clay and organic matter content in the soil. These parameters are directly related to the amount of surface area and surface charge which in turn account for most soil reactions. Clay-size particles and soil organic matter provide most of the total surface area of a mineral soil. Surface charge is also related to these two fractions (Bohn, 1985). Other mineral surfaces, however, and particularly iron oxide coatings, may also contribute substantially to the total number of sortpion sites and overall surface charge, especially in clay-poor sandy soils. Houston et al., (1989) investigated adsorption coefficients for several gases using five different soils, covering a wide range of available surface areas. They found that as the clay content of the soils increases, the available surface area increases and the potential for adsorption also increases. Moreover, since most of the cation exchange capacity is contributed by the clay mineral fraction, the fate of cationic organic pollutants is often controlled by that fraction (Mingelgrin and Prost, 1989).

The $\mathrm{pH}$ of the soil system can greatly influence adsorption of cations, anions, and oxyanions. Many minerals, including oxides, hydroxides, carbonates, and sulfides become hydrated in aqueous solutions. These surfaces can be protonated or deprotonated, as a function of $\mathrm{pH}$, similarly to diprotic acids. The protonation or deprotonation of the surface hydroxyl groups results in the development of positive (at low $\mathrm{pH}$ values), negative (at high $\mathrm{pH}$ values), or no charge at all (at intermediate $\mathrm{pH}$ values), depending on degree of protonation (Stumm, 1992). The $\mathrm{pH}$ values for transition from positive to no charge to negative surface charge are mineral specific, depending on the electronic structure of the mineral, analogous to the charge of a polyprotic acid as a function of $\mathrm{pH}$, electronegativity, and $\mathrm{pK}_{\mathrm{a}}$ (defined below).

Cations and anions may sorb directly to mineral surfaces, losing at least part of their hydration sheath, and becoming essentially part of the surface through the formation of covalent bonds with 
surface oxygens, a process analogous to the formation of inner-sphere complexes in solution. Alternatively, ions may retain their hydration sheath upon adsorption, thereby forming weaker ion-pair complexes, equivalent to outer-sphere solution complexes (Stumm, 1992; Hayes and Leckie, 1987; Hayes et al., 1988). In either case, sorption of cations is accompanied by release of protons in solution and sorption of anions is accompanied by consumption of protons. The adsorption process, therefore, is highly $\mathrm{pH}$ dependent. For many inorganic ions, the extent of sorption may rise from 0 to 100 percent within a $2 \mathrm{pH}$ unit interval. Cations tend to sorb at high $\mathrm{pH}$, whereas anions tend to sorb at low $\mathrm{pH}$. It should be noted, however, that because strong covalent bonds are involved in the formation of inner-sphere complexes, cations may sorb even when the mineral surface is positively charged and conversely, anions forming inner-sphere complexes may sorb even on negatively charged surfaces.

The $\mathrm{pH}$ of the soil system can also affect sorption of organic compounds. Many organic solutes may be charged or uncharged depending on $\mathrm{pH}$ and $\mathrm{pK}_{\mathrm{a}} \mathrm{s}$ of the individual compounds. The $\mathrm{pK}_{\mathrm{a}}$ is the parameter that characterizes the extent of dissociation of a weak acid ( $\mathrm{pK}_{\mathrm{b}}$ for a basic compound) and it is a mathematical description of the effect of acidity (or $\mathrm{pH}$ ) on the protonation of a molecule. The $\mathrm{pK}_{\mathrm{a}}$ is numerically equal to the $\mathrm{pH}$ at which half the acid is dissociated (or negatively charged) and half is undissociated (neutral). The smaller the $\mathrm{pK}_{\mathrm{a}}$, the lower the $\mathrm{pH}$ at which dissociation occurs and hence the stronger the acid (Dragun, 1988; Bohn, 1985). Additionally, dipolar molecules can interact with charged mineral surfaces and in some cases acquire or change their electric charge depending on the $\mathrm{pH}$ of the soil system. Under alkaline, arid soil conditions, dissolved organic molecules can become negatively charged and be repelled by negatively charged minerals. However, these molecules can still be adsorbed by the edges of alumino-silicate clay minerals, the positively charged oxide surfaces, or by hydrogen bonding where the hydrogen atom can serve as a bridge between two negatively charged surfaces.

Soil salinity can have an effect on adsorption reactions if salts in high concentration compete with trace sorbates for ion exchange sites. Salts in high concentration may also reduce the solubility of nonpolar organics (Devinny et al., 1990), which would decrease adsorption and increase mobility. Salts can lower the osmotic component of the water potential; water tends to move into solution of high solute concentration, and becomes more attached to the soil as the concentration of the solute rises.

Saline soils contain large amounts of soluble salts (e.g., salts of $\mathrm{Na}, \mathrm{Ca}$, and $\mathrm{Mg}$, with chloride, sulfate and bicarbonate). Soil salinity is measured in terms of the electrical conductivity. Soils are usually classified according to salinity, $\mathrm{pH}$, and exchangeable sodium percent (ESP). The ratio of exchangeable sodium to the cation exchange capacity, multiplied by 100 , represents the ESP. For ESP values greater than 15 percent, coupled with $\mathrm{pH}$ greater than 8.5, the soil is termed "nonsaline-alkaline." Soils with electrical conductivities exceeding $4000 \mu \mathrm{mhos} / \mathrm{cm}$ are termed "saline." Provided both conditions are met, the soil is "saline-alkali" (Dept. of Agriculture, 1954). The unsaturated zone in arid areas often contains significant quantities of $\mathrm{CaCO}_{3}$ and sometimes $\mathrm{CaSO}_{4}$. The importance of the $\mathrm{CaCO}_{3}$ is in buffering of the $\mathrm{pH}$ of the liquid phase, which in turn affects other soil reactions (Mingelgrin and Prost, 1989). $\mathrm{pH}$ values of 7.5 and greater are common. 
Soil water content affects the adsorption process by modifying the accessibility of the adsorption sites and the surface properties of the adsorbent. The hydration status of the sorption site will strongly influence the interactions of an adsorbate molecule to a particular site. Under very dry conditions, the soil moisture content will determine which sites on the surface will be hydrated or anhydrous (Mingelgrin and Prost, 1989). Moisture content affects the distribution of organic pollutants between the different phases. At low water content, sorption sites of the inorganic surfaces can effectively sorb organic compounds, however, at high water content, sorption of organic compounds is controlled by soil organic matter. Adsorption of a number of organic and volatile organic compounds (VOCs) has been found to be greater as soil moisture decreases (Hance, 1977; Bailey and White, 1964; Yaron and Saltzman, 1977; Estrella et al., 1993; Steinberg and Kreamer, 1993). Studies have shown that soil water content drastically inhibits vapor-phase sorption given that the solubility of the tested gas in water is low. Generally, as the water content goes up, the amount of adsorption of VOCs for a given mass of soil decreases due to a decrease in the surface area available for adsorption (Houston et al., 1989). Water substantially reduces the surface activity of the inorganic surfaces by occupying the high-energy sorption sites. The polar water molecules have a greater affinity for available sorption sites on soils than the nonpolar organics (Yaron and Saltzman, 1977; Hance, 1965). The polar water molecules tend to reduce organic compound sorption, although, organics will sorb, even under saturated condition, because of their hydrophobic behavior (their tendency to avoid the polar water molecules in solution).

The electronic structure of the solute molecule is extremely important in adsorption. The molecular structure defines the nature of the intermolecular forces and determines the ionization potential of a solute molecule (Yaron et al., 1985). The structure of a molecule will determine the inherent behavior of the molecule as well as how the molecule will react with other molecules (Dragun, 1988).

Finally, soil temperature is known to affect sorption. Adsorption processes are typically exothermic and desorption processes are typically endothermic, thus, an increase in temperature would normally be expected to reduce adsorption and favor the desorption process. Increasing soil temperature results in a weakening of the attractive forces between the solute and the solid surfaces and a corresponding increase in solubility of the solute in the solution phase (Yaron et al., 1985; Bailey and White, 1970; Mills and Biggar, 1969; Yaron and Saltzman, 1977).

The previously discussed soil properties are interrelated. For example, Pennel et al., (1992) have suggested that sorption of VOCs is multimechanistic, that is, it might involve sorption onto the soil mineral surfaces, organic matter and soil water. Thus, sorption of VOCs may depend not only on the moisture content but also on the available surface area and organic carbon content of the soil system. Under unsaturated soil conditions, sorption studies have indicated that soil surface area and water content are the primary factors controlling vapor sorption of VOCs (e.g., Steinberg and Kreamer, 1993; Pennel et al., 1992; Yardon et al., 1989; Chiou and Shoup, 1985). In saturated soils, organic carbon content dominates the sorption process of VOCs (Karickhoff, 1984).

\section{Sorption Measurements}

Sorption can be described quantitatively in terms of isotherms. Isotherms are the mathematical representation that demonstrates the relationship between the concentration of the chemical species 
in the sorbent (soil) and its equilibrium concentration in solution at constant temperature. The extent of adsorption of a chemical species may be expressed by an adsorption or distribution coefficient derived empirically from an adsorption isotherm. Many types of isotherms have been used to parametize adsorption-desorption measurements. Among the most successful is the Freundlich isotherm:

$$
S=K_{f} C^{n}
$$

where $S$ is the adsorbed chemical species concentration in mass per mass of soil ( $\mu \mathrm{g} / \mathrm{g}$ soil), $\mathrm{C}$ is the solution phase concentration in mass per volume of solute $(\mu \mathrm{g} / \mathrm{mL}), \mathrm{K}_{\mathrm{f}}($ or $\mathrm{K})$ is the Freundlich coefficient $(\mathrm{mL} / \mathrm{g})$ and $\mathrm{n}$ is the exponent which lies between 0 and $1 . \mathrm{K}$ and $\mathrm{n}$ are empirical coefficients that depend on the specific soil-contaminant system (or solute-sorbent system). The logarithmic form of equation (1) is expressed as

$$
\log S=\log \mathrm{K}+\mathrm{n} \log \mathrm{C}
$$

where $\mathrm{K}$ and $\mathrm{n}$ represent the intercept and the slope on a $\log -\log$ plot of $\mathrm{S}$ vs. C, respectively. When $\mathrm{n}=1$, then equation (1) is linear and an even simpler linear adsorption equation can be used:

$$
S=K_{d} C
$$

where $K_{d}$ is the distribution coefficient (Rao and Davison, 1980).The error introduced by assuming linearity for a nonlinear adsorption-desorption process depends on $\mathrm{C}$ and $\mathrm{n}$. This error can be represented as the ratio of equations (1) and (3) and is equal to $\mathrm{C}^{\mathrm{n}-1}$. Such error may be tolerable for many practical applications, but for high solution concentrations, the amount adsorbed could easily be overestimated by an order of magnitude or more (Rao and Davison, 1980).

A common method used to measure adsorption-desorption is the "batch" equilibrium technique. In this method, soil samples (sorbent) are suspended by shaking until equilibrium is attained with a series of solution concentrations (solute) and the changes in the solution concentration are attributed to sorption (Green et al., 1980). When using this method, it is assumed that most of the sorption sites are exposed by the gentle shaking of the slurry. Therefore, the $\mathrm{K}_{\mathrm{d}}$ obtained would thus be a maximum. However, studies have shown that the degree of adsorption is not always the same in slurry studies (saturated conditions) and in soil water systems with lower water content (Hance, 1977; Bailey and White, 1964; Estrella et al., 1992). Most vadose zone contaminant transport models assume that sorption values for saturated soils are applicable for unsaturated conditions (Schmeltzer, 1993). This assumption does not correctly reflect the processes occurring in unsaturated soils (Culver et al., 1991). Sorption studies have shown how an increase in the soil moisture greatly reduces the sorption of organics and volatile organics onto soils, in some cases by orders of magnitude (e.g., Chiou and Shoup, 1985; Peterson et al., 1988; Houston et al., 1989; Yardon et al., 1989; Steinberg and Kreamer, 1993).

Experimental $K_{d}$ values are very site specific, each characterizing a very particular subsurface system (that is, the soil solution, mineralogy and the specific chemical). Because of the unique nature 
of the $K_{d}$, it is very difficult to compare the different $K_{d}$ values from the literature. Unless a general relationship of the multiple parameters influencing the $\mathrm{K}_{\mathrm{d}}$ values is established, not much can be achieved by comparing them (Kaufman, 1963).

\section{Sorption at the Area 5 RWMS}

The Area 5 RWMS is located on the Nevada Test Site (NTS), north of the Frenchman Playa, near the junction of three alluvial fans within the Frenchman Lake drainage basin (Dozier and Rawlinson, 1991). Several studies have been conducted around the Frenchman Flat area investigating the mineralogy, and the physical and chemical properties of the alluvial material (Wolfsberg, 1979; Romney et al., 1973; Kautsky, 1984; Jones, 1982; Daniels and Thompson, 1983; Case et al., 1984; Case et al., 1992; Steinberg and Kreamer, 1993; REECo, 1993a; REECo, 1993b). Some of the alluvial soil properties related to sorption are summarized in Table 1 by study. In discussing sorption at the Area 5 RWMS, it will be helpful to describe first the location and type of investigation conducted for such studies. A discussion of the specific conditions affecting sorption at the RWMS will follow.

TABLE 1. SUMMARY OF SOIL PROPERTIES RELATED TO SORPTION AT THE AREA 5 RWMS OF THE NEVADA TEST SITE AND VICINITY.

\begin{tabular}{lccccccc}
\hline \hline \multicolumn{1}{c}{ Reference } & $\mathrm{pH}$ & $\begin{array}{c}\text { CEC } \\
\mathrm{meq} / \\
100 \mathrm{~g}\end{array}$ & $\begin{array}{c}\mathrm{EC}\left(^{* *}\right) \\
\mathrm{cm} /\end{array}$ & $\begin{array}{c}\text { ESP } \\
\%\end{array}$ & $\begin{array}{c}\text { Clay } \\
\%\end{array}$ & $\begin{array}{c}\text { Silt/Clay } \\
\%\end{array}$ & $\begin{array}{c}\text { Clay Fraction } \\
\text { Mineralogy }\end{array}$ \\
\hline $\begin{array}{l}\text { REECo, } \\
1993 \mathrm{a}, \mathrm{b}\end{array}$ & $8.2-9.1$ & & $191-1520$ & & & $>10$ & \\
$\begin{array}{l}\text { Case et al., } \\
1992\end{array}$ & $8.1-9.9$ & & $103-2810$ & & & & \\
Kautsky, 1984 & $8.1-9.3$ & $13-30$ & $100-4400$ & $1-35$ & $5-15$ & & $\begin{array}{l}\text { montmorillonite, } \\
\text { illite, clinoptillite } \\
\text { quartz, feldspar, } \\
\text { clinoptillite }\end{array}$ \\
$\begin{array}{l}\text { Jones, 1982(*) } \\
\text { Romney et al., }\end{array}$ & $7.6-8.9$ & $5.8-17.8$ & $440-6500$ & $2.6-40$ & & & \\
$\begin{array}{l}1973 \\
\text { Steinberg and } \\
\text { Kreamer, 1993 }\end{array}$ & & $58-120$ & & & & $0.4-5$ & $\begin{array}{l}\text { calcite, quartz, } \\
\text { anorthite }\end{array}$ \\
\hline \hline
\end{tabular}

$\left(^{*}\right)$ Jones $(1982)$ analyzed the $<0.1 \mu \mathrm{m}$ fraction.

$\left.{ }^{* *}\right)$ Electrical conductivities of the 1:1 soil to water extracts.

Three Pilot Wells and seven Science Trench boreholes have been drilled near the Area 5 RWMS (REECo, 1993a, 1993b). Laboratory tests were conducted on representative geologic samples from the Pilot Wells and the Science Trench boreholes to quantify the vertical distribution of hydrologic, geochemical and mineralogic parameters. Selected core samples from the Pilot Wells and the Science Trench boreholes were analyzed by X-ray fluorescence (XRF) for major elements $\left(\mathrm{SiO}_{2}\right.$, $\mathrm{TiO}_{2}, \mathrm{Al}_{2} \mathrm{O} 3, \mathrm{Fe}_{2} \mathrm{O}_{3}, \mathrm{MnO}, \mathrm{MgO}, \mathrm{CaO}, \mathrm{Na}_{2} \mathrm{O}, \mathrm{K}_{2} \mathrm{O}$ and $\left.\mathrm{P}_{2} \mathrm{O}_{5}\right)$ and trace elements $(\mathrm{Rb}, \mathrm{Sr}, \mathrm{Zr}, \mathrm{Y}$, $\mathrm{Nb}, \mathrm{Pb}, \mathrm{Th}$ ). Selected core samples were also analyzed for the following elements by instrumental neutron activity analysis (INAA): $\mathrm{FeO}, \mathrm{Na} 2 \mathrm{O}, \mathrm{Sc}, \mathrm{Cr}, \mathrm{Zn}, \mathrm{As}, \mathrm{Br}, \mathrm{Sb}, \mathrm{Cs}, \mathrm{Ba}, \mathrm{La}, \mathrm{Ce}, \mathrm{Nd}, \mathrm{Sm}, \mathrm{Eu}$, 
$\mathrm{Tb}, \mathrm{Yb}, \mathrm{Lu}, \mathrm{Hf}, \mathrm{Ta}, \mathrm{Th}$, and $\mathrm{U}$. Results from all of these analyses are found in REECo (1993a, 1993b). REECo has reported the following: the alluvium at the Area 5 RWMS has a basic rhyolitic composition of approximately 65 percent $\mathrm{SiO}_{2}, 13$ percent $\mathrm{Al}_{2} \mathrm{O}_{3}$, and all other major elements total less than 5 percent. Inorganic carbon concentrations are very low (average less than 1 percent by weight) and fairly constant through the profile. Organic carbon values are generally an order of magnitude lower $(0.05$ percent by weight) and equally constant. The alluvium is primarily coarse grained, composed of sand-size particles with considerable amounts of gravel and generally less than 10 percent by weight of fines (silt and clay fraction combined). Soils are very dry near the surface with only a slight increase in water content with depth and a very significant increase near the water table. The mean water content for the first $36.6 \mathrm{~m}$ is approximately 5 percent by weight.

Steinberg and Kreamer (1993) investigated the vapor phase sorption of several VOCs by unsaturated calcareous soils from the NTS in the vicinity of Frenchman Flat. Soil samples were taken from the Area 5 RWMS (Pit 3) at approximately $6 \mathrm{~m}$ below the surface. Inverse Gas Chromatography (IGC) methods were used to evaluate sorption of VOCs. The partition coefficients (K) obtained with the IGC method are restricted to the kinetically fast interactions (instantaneous sorption) between the sorbent and the sorbate (Table 2). Sorption capacities of the clay and silt and the medium-to-fine sand fraction of the soil were investigated at various soil water contents and different temperatures. Partition coefficients $(\mathrm{K})$ from the medium-to-fine sand were lower than the clay-size fraction, showing, however, a good correlation between the data sets. This indicates that the sorption mechanism is most likely the same and partially a function of surface area. A small increase in water content drastically decreased the sorption of non-hydrogen-bonding VOCs by soils. However, the hydrogen-bonding compounds (e.g., diethyl ether, acetone, and acetonitrile) exhibited finite sorption and desorption kinetics in the presence of water.

TABLE 2. PARTITION COEFFICIENTS (K) REPORTED BY STEINBERG AND KREAMER (1993) FOR VOCS USING THE SILT AND CLAY-SIZE FRACTION AT 1.65 PERCENT GRAVIMETRIC WATER CONTENT.

\begin{tabular}{lrrr}
\hline \hline \multicolumn{1}{c}{ Compound } & $30^{\circ} \mathrm{C}$ & $\mathrm{K}(\mathrm{mL} / \mathrm{g})$ & $40^{\circ} \mathrm{C}$ \\
\hline Pentane & 0.28 & & $50^{\circ} \mathrm{C}$ \\
TCE & 1.74 & 1.08 & 0.69 \\
PCE & 2.78 & 1.59 & 0.92 \\
TCA & 1.86 & 1.11 & 0.67 \\
TeCA & 35.79 & 18.87 & 9.40 \\
Benzene & 3.01 & 1.68 & 0.99 \\
Toluene & 8.43 & 3.57 & 2.98 \\
Ethylbenzene & 18.61 & & \\
Acetonitrile & 204.20 & & \\
Acetone & 158.50 & & \\
Diethyl ether & 15.49 & & \\
\hline \hline
\end{tabular}


Case et al., (1992) quantified lead sorption and compound formation from soils at the Area 5 RWMS. Soil samples from the surface and near-surface $(3.7-14.3 \mathrm{~m})$ were selected for the lead adsorption studies. The batch equilibration method was used. They found that the carbonate content of the soils at the Area 5 RWMS provides an effective barrier to lead migration. Lead is precipitated when it associates with the soluble carbonate and adsorbed by the insoluble mineral carbonate to form predominantly lead carbonate, which is essentially immobile. Lead adsorption by the mineral carbonate fraction at the site is the dominant binding mechanism, but precipitation with the soluble carbonate fraction is also significant.

Kautsky (1984) studied the sorption and ion exchange properties of $\mathrm{Cs}^{+}$and $\mathrm{Sr}^{2+}$. The study area was located approximately $402 \mathrm{~m}$ east of the Area 5 RWMS and samples were taken from the top 1.5 to $6 \mathrm{~m}$. Kautsky classified the soil as fine sandy loams and loamy sands, low clay (5-15 percent) and low organic content, and gravelly (20-40 percent gravel -- fragment $>5 \mathrm{~mm}$ in diameter), with 10-40 percent cobbles composed mainly of silicic ash-flow tuffs. He categorized the soils as nonsaline-alkali changing to saline-alkali in a few locations (Dept. of Agriculture, 1954). Upon examination of the exchangeable cations of the soils, the $\mathrm{Ca}^{2+}$ ion predominantly occupied the available exchange sites, followed by $\mathrm{K}^{+}$and $\mathrm{Na}^{+}$, and $\mathrm{Mg}^{2+}$ being the least abundant. Kautsky conducted batch sorption studies and reported that the soils at the study site contain minerals which sorb $\mathrm{Cs}^{+}$and $\mathrm{Sr}^{2+}$ preferentially over naturally occurring exchange phase cations. He also noted that montmorillonite has a greater affinity for sorption of $\mathrm{Sr}^{2+}$, and that illite, clinoptillite, and mica preferentially sorb $\mathrm{Cs}^{+}$.

Jones (1982) studied the mineralogy of fine-grained alluvium from northern Frenchman Flat, $6 \mathrm{~km}$ north of Frenchman Playa. Jones was interested in looking for "chain" clays as an indicator of movement of water table levels through time. He analyzed the less than 1-mm-size fraction and presented analyses on samples from borehole U11g, collected 160-329 m below the surface. He found no "chain clays," but his study is important because it provides deep subsurface data (see Table $1)$.

Romney et al., (1973) investigated the nature and properties of the soils over several study areas on the southern half of the NTS, including the Frenchman Flat area. Even though the emphasis of this study was on the relation of the soil characteristics relating to the distribution of vegetation, they examined and reported shallow soil sample properties. Some of their findings are summarized on Table 1.

Wolfsberg (1979) conducted batch sorption-desorption studies and determined distribution coefficients $\left(\mathrm{K}_{\mathrm{d}}\right)$ for radioactive tracers using the alluvium from the Cambric investigation in Area 5, borehole U5e(RNM-1), located $3 \mathrm{~km}$ south of the Area 5 RWMS and from Yucca Flat in Area 3. At the Cambric investigation, samples were taken from $238 \mathrm{~m}$ and $331 \mathrm{~m}$. Wolfsberg's $K_{d}$ values for Area 5 are found in Table 3.

Daniels and Thompson (1983) conducted laboratory studies emphasizing the sorptive behavior of alluvium and tuff and its dependence on mineralogy at the Cambric site. The batch sorption-desorption studies were performed using alluvium material from RNM-1 at a depth of $331.5 \mathrm{~m}$. Pertinent findings are summarized in Table 3. 
TABLE 3. SUMMARY OF SORPTION COEFFICIENTS $\left(\mathrm{K}_{\mathrm{d}}\right)$ FROM SOILS AT THE AREA 5 RWMS OF THE NEVADA TEST SITE AND VICINITY.

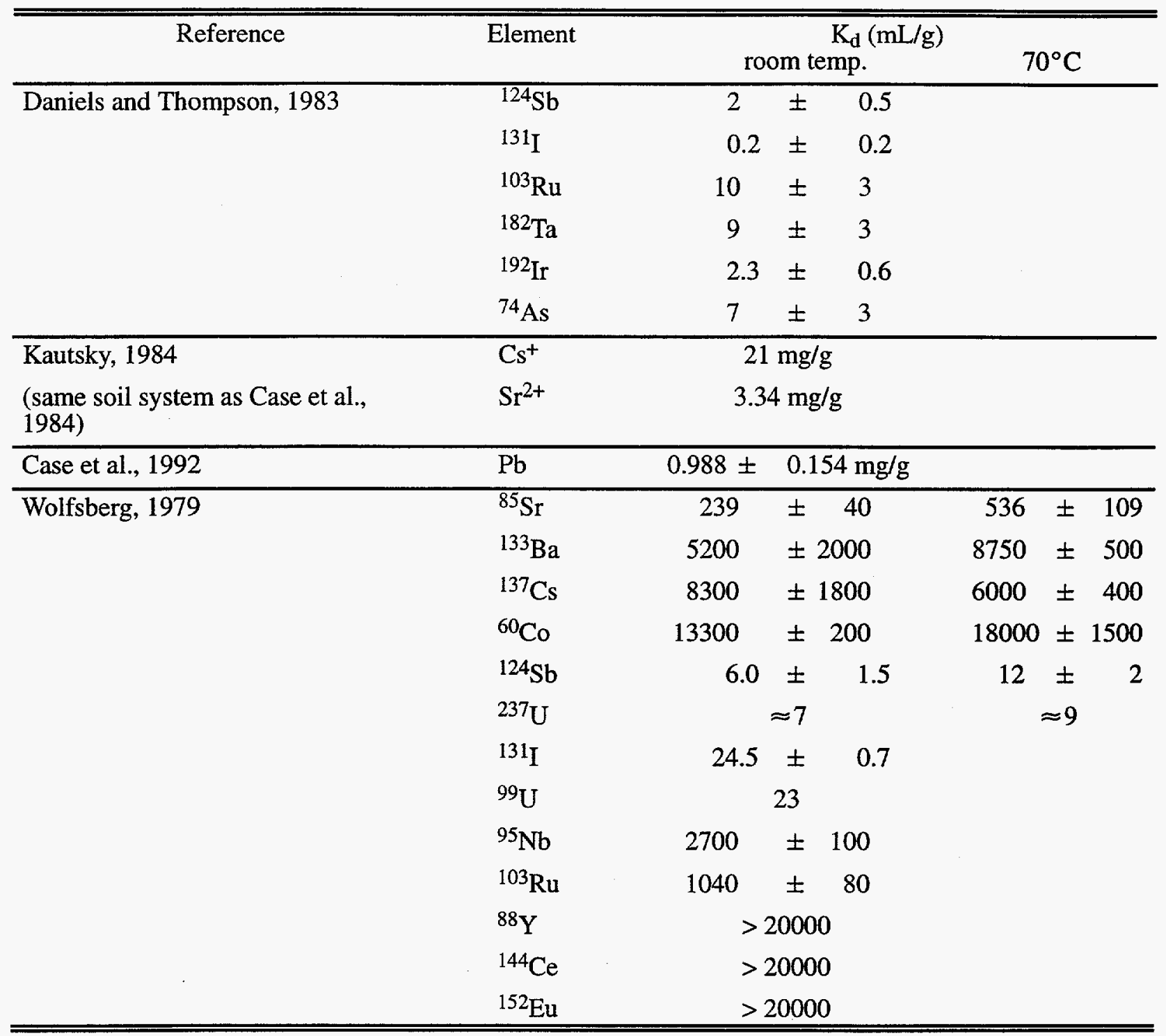

The particular conditions and alluvial properties that might affect sorption will now be discussed. Generally, the soil at the Area 5 RWMS is composed of sand-size particles which offer little in the way of sorptive surfaces. Nonetheless, the soil also has up to 10 percent silt and clay fractions combined (Table 1), and just a small percent of the silt and clay fraction can result in a substantial increase in soil sorptive capacity (Piwoni and Keeley, 1990). The soil at the Area 5 RWMS has a very low organic carbon content (less than 0.05 percent by weight). Sorption of nonpolar (neutral) molecules (e.g., nonpolar organics) is controlled by weak interactions, primarily hydrophobic bonding with the nonpolar organic phase (Sutton and Barker, 1985). Such a low organic carbon content will not contribute in any significant way to hydrophobic sorption. However, even if organic molecules are best adsorbed by organic matter, organic chemicals will adsorb strongly to the surface of mineral soil particles if the soil is very dry (Valsaraj and Thibodeaux, 1988). The soils at the RWMS are indeed very dry near the surface, having a water content ranging 
from 2.5 to 6 percent by weight in the top $7.6 \mathrm{~m}$. Soil mineral surfaces at the site may effectively sorb organic compounds at this low water content. Steinberg and Kreamer (1993) showed how the silt and clay fraction of the soil at Area 5 could effectively sorb VOCs. Moreover, the $\mathrm{pH}$ of the soils at the Area 5 RWMS ranges from 7.6-9.9 (Table 1). At these $\mathrm{pH}$ values, most mineral surfaces will be either neutrally or negatively charged and significantly contribute to the adsorption of cationic species (e.g., metals). Electrical conductivity of the soils at the Area 5 RWMS ranges from 100 to $6500 \mu \mathrm{mhos} / \mathrm{cm}$ ( $1: 1$ soil water extract). The high concentration of soluble salts in some areas could have a number of different effects on adsorption. As mentioned earlier, the unsaturated zone in arid environments often contains significant amounts of $\mathrm{CaCO}_{3}$. Case et al., (1992) found that the carbonate fraction of the soils at the RWMS effectively sorb and precipitate lead to form lead carbonate, which is essentially immobile.

The Area 5 RWMS soil under the prevailing current conditions can provide an effective barrier to the movement of a number of organic and inorganic contaminants. Quantitative determinations for lead and radioactive tracers have been made with soil samples from the Area 5 RWMS and vicinity (Case et al., 1992; Kautsky, 1984; Case et al., 1984; Daniels and Thompson, 1983; Wolfsberg, 1979). Steinberg and Kreamer (1993) have conducted experiments addressing the attenuation of organics with these soils. Tables 2 and 3 summarize the results of the soil studies conducted at Area 5 and vicinity in the form of adsorption coefficients $\left(K_{d}\right)$, sorption ratios $\left(R_{d}\right)$ and/or partition coefficients (K).

The values reported in Table 2 for different VOCs refer to the clay and silt fraction of the soil at a particular moisture content ( 1.65 percent by weight). These fine particles are indeed expected to be the soil fraction that provides most of the sorption sites for VOCs. However, it should be kept in mind that this fraction, according to Steinberg and Kreamer (1993), represents just up to 5 percent (w/w) of the soil at the site. Even though the values on Table 2 are very specific for that particular moisture content, this study is important because it shows that the soil at the site has the potential to sorb VOCs, especially when soils are very dry.

Experimental $\mathrm{K}_{\mathrm{d}}$ values are very site specific, categorizing a particular subsurface system and specific geochemical conditions (Kaufman, 1963). Thus, it is not surprising to find differences between $K_{d}$ estimates (Table 3). Wolfsberg (1979) and Daniels and Thompson (1983) conducted batch sorption studies for radioactive tracers using soil samples from the same borehole at the Cambric site. Their $\mathrm{K}_{d}$ estimates were different. These differences could be due to a number of factors. They both reported $R_{d}$ values (sorption ratios) instead of $K_{d}$ values (distribution coefficients). $R_{d}$ does not imply equilibrium, but is otherwise identical to $K_{d}$. The sorption ratio $\left(R_{d}\right)$ is defined as the ratio of the concentration of a species per gram of solid phase to the concentration of the species per milliliter of aqueous phase. Thus, since equilibrium is not assured or implied with the $R_{d}$ values, differences in shaking (or contact) times would result in different $R_{d}$ values. Daniels and Thompson (1983) reported a loss of some of the nuclide to the polyethylene containers in which the experiments were performed. Wolfsberg et al. (1979) also used polyethylene containers but different shaking times and solution compositions, allowing for the different sorption ratios between the soil and the container. Furthermore, the $\mathrm{K}_{\mathrm{d}}$ values in Table 3 were all obtained using the "batch" method, that is, they were all slurry studies performed under saturated conditions. A number of 
studies have shown that the degree of adsorption is not always the same in slurry studies (saturated conditions) and in soil water systems with lower water content (Hance, 1977; Bailey and White, 1964; Estrella et al., 1992). Batch tests are very useful when evaluating the relative adsorption characteristics of different soil types for a particular compound, however column experiments simulate field conditions much better (Houston et al., 1989; Griffin, 1981).

Thus, regarding the applicability of the available sorption data for radioactive tracers and lead (Table 3), it is not certain that they would be accurate under a different set of conditions; variable soil moisture content or different ionic strength of the solution. Under the present climatic conditions, saturated conditions at the site would only be a short-lived transient state (possibly immediately after a rain storm) and confined only to the near surface (upper $3 \mathrm{~m}$ ) (REECo, 1993c). The values reported in Table 3 used groundwater to prepare the equilibrating solution, which may directly affect the experimental results. Estrella et al., (1993) reported that the ionic strength of the soil solution is much higher than that of the groundwater at Area 5. An increase in ionic strength decreases the thickness of the diffuse double layer ((DDL) - distance over which the solution concentration is affected by the colloid charge), which in turn can affect adsorption. (For a detailed DDL theory interpretation, see Kautsky, 1984.) Wolfsberg (1979) conducted batch sorption studies and calculated distribution ratios $\left(R_{d}\right)$ for $Y$ ttrium $(Y)$ using distilled water and groundwater. The $R_{d}$ for Yttrium using distilled water was almost double that for groundwater $(24,600 \mathrm{~mL} / \mathrm{g}$ vs. $13,700 \mathrm{~mL} / \mathrm{g}$ ). Distilled water caused swelling and dilution of the DDL. The resulting dilution caused the trivalent cation $\mathrm{Y}^{3+}$ in the solution to displace more easily the divalent $\left(\mathrm{Ca}^{2+}\right)$ and monovalent $\left(\mathrm{K}^{+}, \mathrm{Na}^{+}\right)$cations from the clay mineral surfaces. 


\section{TRANSFORMATION PROCESSES}

\section{Chemical Transformations}

It is difficult to distinguish between chemical and biological degradation reactions. In general, the experimental approach is to compare the transformations which occur in natural and sterile soils (Yaron et al., 1985; Torstensson, 1988). Chemical reactions affect contaminant transport by changing the form of the contaminant, which subsequently alters the interactions between the contaminant and the stationary subsurface material (Knox et al., 1993). Even though non-biological reactions have been proposed as the main degradation mechanisms of only a few chemical species, these reactions can play a significant role in mediating biological reactions (Torstensson, 1988). A chemical species or contaminant can undergo chemical degradation in soils either in solution or adsorbed to the solid phase. Chemical degradation can occur as a hydrolytic process, as a result of oxidation-reduction or other non-hydrolytic reactions (Yaron, 1989).

Hydrolysis refers to any reaction that involves the dissociation of water into $\mathrm{H}^{+}$and $\mathrm{OH}^{-}$by the action of a substance that will combine with either species (Yaron et al., 1985). Exchangeable hydrated and anhydrous ions have a localized electric charge which creates a strong electric field around them. This field brings about polarization and dissociation of adsorbed species and, in particular, the cations' hydration water. The polarization and dissociation of water molecules in the hydration shell of exchangeable cations, in turn, enhance many surface reactions (Mingelgrin and Prost, 1989).

Oxidation-reduction reactions involve the transfer of electrons between dissolved, gaseous, or solid constituents. Oxidation is the loss of electrons by a chemical species and reduction is the gain of electrons. Every oxidation reaction is accompanied by reduction of another species and vice versa, so that electrons are conserved. In every redox system, therefore, an oxidation reaction must be coupled with a reduction reaction. These reactions involve transfer of electrons and must be coupled in such a way so that the overall, combined redox reaction contains no net electrons, to represent the fact that free electrons do not exist in solution. The two half-reactions must be combined in such a way so that the Gibbs free energy of the combined reaction is negative, i.e., the reaction proceeds spontaneously as written. Noting that every half-reaction contains a reduced and an oxidized species, the reaction will be spontaneous as written if the stronger oxidizer (of one half-reaction) is oxidizing the reducer of the other half-reaction.

\section{Biological Degradation}

Biodegradation refers to any biologically induced structural transformation in the original parent compound that changes its molecular integrity (Scrow, 1982). Many organic substances break down faster when adsorbed on certain solids than when in solution, however, many of them become less biologically available through sorption (Hurle and Walker, 1980; Macalady and Wolfe, 1985). Adsorption affects both the mobility and microbial transformations of adsorbed molecules. Because of sorption, only a fraction of the total amount of a pollutant in a contaminated soil may be available for degradation at any given point in time. This does not mean that extensive or total degradation cannot occur, but it may occur at a rate limited by desorption from the soil (Ogram et al., 1985; Speitel et al., 1989). 
Like most processes occurring in nature, biodegradation is dependent upon numerous chemical and environmental factors and conditions (e.g., temperature, moisture, $\mathrm{pH}$, chemical concentration). Soil microorganisms in arid environments are subjected to the same external physical factors as in other soils, except that the organisms are subjected to prolonged harsh environmental extremes (Skujins, 1984). Relatively little detailed information about arid-soil biological processes is available in comparison with the body of knowledge about physical and biological processes of marginally utilizable arid areas or semiarid cultivated soils ( Skujins, 1984; Focht and Martin, 1979; Andraski, 1992).

Soil temperature fluctuates daily and seasonally, particularly at the soil surfaces. Individual species of soil microorganisms differ in their response to variations in temperature and optimum temperature ranges. Generally, however, cold temperatures approaching freezing essentially stop microbial growth without killing the organism. The optimum soil temperature for most soil microorganisms is between $25^{\circ}$ and $35^{\circ} \mathrm{C}$. Temperatures higher than $35^{\circ} \mathrm{C}$ can gradually start killing cells, depending on the heat tolerance of the species (Singer and Munns, 1987). Nonetheless, higher temperatures that do not kill the microorganisms generally result in higher metabolic activities. Many organisms in desert soils may survive surface soil temperatures reaching higher than $70^{\circ} \mathrm{C}$, however, microbial growth in desert soils may occur mostly at lower temperatures coinciding with prolonged availability of water.

Moisture content may determine the relative importance of biotic and abiotic processes. Soil water affects not only the moisture available to organisms, but also the soil aeration status (e.g., oxygen levels), the nature and amount of soluble materials, the osmotic pressure, and the $\mathrm{pH}$ of the soil solution. Water conditions are rarely ideal for soil microorganisms. Generally, microbial activity in soils is optimal at a soil matric potential of $-0.01 \mathrm{MPa}$. As soils get drier, the water films become thinner, limiting the movement of the soil microorganism and their nutrients. Extremely dry conditions (drought) produce a set of stresses for which the microorganisms must either adapt to desiccation, prevent desiccation, or die (Singer and Munns, 1987). Microorganisms living in dry desert soils must be able to tolerate long periods of desiccation (Skujins, 1984). Many bacteria can prevent desiccation and adapt to low water potentials and high salinity by maintaining a high internal concentration of solutes. Even when they do desiccate, some bacteria survive due to their small size, ruggedness and simple structure. Drought survivors may be only a small number, but when water becomes available again, they start multiplying using the plentiful food in the form of dead microbial cells (Singer and Munns, 1987). Some bacteria and fungi living in desert soils can form spores that allow them to persist even for decades between growth periods. When water becomes available, the spores germinate and the microorganisms can actively grow and reproduce (Atlas and Bartha, 1987). Nonetheless, most microorganisms in desert soils are neither spore formers nor develop any restricting structures (Skujins, 1984). Elwan and Diab (1970) showed that in very dry sands (0.95-2.5 percent water) which were also poor in organic matter (.09-.033 percent organic C), at least 84 percent of the bacteria was in a vegetative state. They suggested that moisture from dew was possibly sufficient to maintain the active state of bacterial cells for a few hours after sunrise. Rychert et al. (1978) have also shown some evidence indicating that during the dry season, soil microorganisms may respond to dew, with higher microbial activity during morning hours before the soil dried. Under very dry soil conditions, however, microbial activity is inhibited, and the 
relative contribution of biotic processes to the dissipation of organic pollutants is not likely. No significant microbial proliferation may be expected at water potentials < -40 MPa (Skujins, 1984).

Desert soils are usually characterized by high soil $\mathrm{pH}$ and high salinity, both of which influence the activities of soil microorganisms (Skujins, 1984). Soil pH can affect degradation either through its effect on the stability of the chemical, by its effect on adsorption, or the makeup of the microflora (Yaron et al., 1985). Microorganisms generally cannot tolerate extreme $\mathrm{pH}$ values, however, the optimal $\mathrm{pH}$ values and the tolerance of ranges of $\mathrm{pH}$ vary for different species. Optimal $\mathrm{pH}$ values may depend on other factors, such as salt concentration. High salt concentrations tend to dehydrate cells and denature enzymes. Nonetheless, many bacteria in dry desert soils can adapt to high salinity by maintaining a high internal solute concentration.

Recent investigations of deep subsurface microbial ecology have found evidence of abundant and diverse microbial populations at depths of 500 to $600 \mathrm{~m}$ (Wobber, 1990) which are capable of degrading a variety of hazardous organic compounds (Sutton and Barker, 1985). The number, type, and distribution of microorganisms in shallow and deep subsurface sediments are generally similar, however, there are some site-specific differences which correlate to the subsurface characteristics. For example, population numbers and activity detected in sandy transmissive sediments are higher than those which have a larger clay fraction (Thomas and Ward, 1992). Both shallow and deep subsurface samples show bacteria as the predominant type of microorganism.

Microorganisms in desert soils exhibit a certain degree of vertical and horizontal stratification. The microbial activity in arid soils is usually concentrated on the soil surface, and especially in the root zone or rhizosphere. Some microorganisms in arid zones can grow within the rock matrix (Friedmann and Ocampo, 1976; Friedmann and Ocampo-Friedmann, 1984). These endolithic microorganisms adhere to or grow between the rock crystals. The uppermost 1-3 $\mathrm{mm}$ of the rock are free from microorganisms and colonies are found in the next few millimeters. In hot deserts, all endolithic samples examined by Friedmann and Ocampo-Friedmann (1984) contain only procaryotes (bacteria), which formed a narrow green zone a few millimeters below and parallel to the rock crust.

Microorganisms can theoretically metabolize most organic compounds and use them as a source of carbon or cellular energy. Certain classes of compounds can be biologically degraded fairly easily and others, like those with high molecular weights or highly chlorinated compounds, are more difficult to metabolize. However, the real power of microorganisms stands in their adaptability. Given their short reproductive cycles, microorganisms can evolve relatively quickly to develop a biochemical trait that might give them a selective advantage. Those microbes that develop the ability to use a new food source (e.g., xenobiotic compounds, hazardous wastes) will begin to grow and proliferate (Glass, 1991).

\section{Transformation Processes at the Area 5 RWMS}

Little detailed information about arid-soil biological processes is available and none was found specifically for the Area 5 RWMS. Under harsh arid conditions, long periods of dryness often minimize the importance of biotic interactions. Low organic matter content, even at the surface, 
maximizes the role of the mineral fraction in the abiotic interactions. Without knowing the microbial numbers, distribution and activities at the Area 5 RWMS it is difficult to assess the role biodegradation plays on the fate of the waste at the repository. Preliminary studies should be conducted to evaluate the microbial community of the Area 5 RWMS soils. The focus of such studies should be to determine the relative potential of any biochemical cycling. Not only the qualitative and quantitative microbiological aspects of the ecosystem require further investigation, but also the activities of the microorganisms need to be known, because only active organisms have an ecological impact. Numbers, biomass, and metabolic activities are the fundamental biotic parameters of microbial ecosystems (Atlas and Bartha, 1987).

Common methods for enumerating microorganisms are: 1) direct count procedures (e.g., direct microscopic observations of acridine orange-stained cells, and 2) indirect or viable count procedures (e.g., plate count techniques and most probable number (MPN) techniques). Direct count procedures, however, fail to distinguish living from dead microorganisms, and it is not possible to perform further studies on the observed microorganisms. Direct count procedures are useful in estimating bacterial numbers in filtrates (e.g., a water column), but are complicated by the presence of soil particles. Indirect or viable count procedures require the separation of microorganisms into individual reproductive units as well as the culture of selective types of microorganisms (e.g., bacteria, fungi). These methods consistently underestimate the microbial communities when compared with direct count techniques. The "total viable count" obtained by viable count procedures typically enumerates only about 1 percent of a microbial community (Atlas and Bartha, 1987). Common methods of estimating microbial activity in nature are through the use of radioisotopes, microelectrodes, and stable isotopes. Radioisotopes (e.g, ${ }^{14} \mathrm{C}$ ) are highly sensitive (Brock and Madrigan, 1991).

New methods of bacterial enumeration that require neither growth nor removal of cells from the soil surfaces have been developed (White, 1983). These methods can measure biomass ("mass of living material") as well as metabolic activities. These are nonselective methods for analyzing intact microbial consortia that are acquired by an assessment of the biochemical properties of cells. Specific biochemical constituents are restricted to particular subsets of the microbial community which are called the "signature" component of that specific microbial group. These "signatures" can give information about the community biomass, composition and activity.

The strengths and limitations of these methods should be kept in mind when making estimates about a given microbial community. If the microbial ecology at the Area 5 RWMS is investigated, it would be interesting to compare microbial population characteristics from a site close to waste already in place and a site further away to see whether or not any changes (acclimation or adaptation) have occurred. 


\section{TRANSPORT PROCESSES}

The movement and distribution of hazardous wastes in the vadose zone can be affected by three major mechanisms: 1) advection (mass flow or convective transport), 2) liquid dispersion (hydrodynamic dispersion), and 3) vapor flow within soil air-filled voids. The relative magnitude of the liquid and vapor flux in desert soils is important in prediction of contaminant transport from waste disposal facilities (Scanlon, 1992). In this section, emphasis is placed on vapor flux processes. Liquid flux studies in the area have been conducted by Conrad et al. (1993) and Detty et al. (1993).

\section{Liquid Flow}

Mass flow of dissolved solutes within moving soil solution as well as liquid dispersion within the soil solution are not expected to be important transport mechanisms at the Area 5 RWMS. Liquid waste will be excluded from the Area 5 RWMS; thus, any liquid or moving soil solution would have to come from an external source (e.g., precipitation). Furthermore, the quantity and rate of infiltration in the area has been demonstrated to be extremely low (Detty et al., 1993). Low precipitation and high evapotranspiration rates will limit the potential quantity of dissolved solute movement within the soil. The average precipitation in the region is approximately $10 \mathrm{~cm}$ per year and the estimated evapotranspiration rate is $220 \mathrm{~cm}$ per year (EG\&G/SAIC, 1991).

\section{Gas Flow}

Experimental modelling of the mobility of hazardous constituents in the gas phase at the Area 5 RWMS is being conducted by Reynolds Electrical \& Engineering Company (REECo), Special Projects Section. Given that gas transport will be the most likely transport mechanism at the Area 5 RWMS, a general discussion of the factors affecting gas flow and the particular conditions at the Area 5 RWMS will be addressed in the following section.

In general, gas moves through soils by either diffusion, advective flow, or some combination thereof. Diffusion is the process by which solutes move under the influence of their kinetic activity in the direction of a concentration or temperature gradient (Freeze and Cherry, 1979). Diffusion is the average rate of migration or velocity of a chemical in response to a specific gradient (Dragun, 1988). Concentration diffusion (or ordinary gaseous diffusion) is a process in which chemicals migrate from a region of higher to one of lower concentration (Dragun, 1988). Thermal gaseous diffusion occurs when a temperature gradient is established in a gaseous mixture causing the less dense molecules (lighter compounds) to move in the direction of increasing temperature (Tyler et al., 1986; Dragun, 1988). If a temperature gradient is maintained, the gases will continue to separate until concentration diffusion balances thermal diffusion.

Advective flow is the process by which a solute moves in response to a pressure gradient. Unlike diffusion, advection occurs as a bulk flow in which a mixture of gases behaves as one gas. Thermal advection is caused by a thermally induced pressure gradient. As temperature increases, the heated gases will flow in response to the corresponding increase in pressure in an effort to reestablish a pressure equilibrium. The thermal advection contribution to the overall vapor transport, particularly at depth, however, will be limited. Soils act as natural insulators creating a phase lag in temperature with depth. Provided there is a heat generating source below ground surface, thermal 
advection could become significant. Other factors which produce pressure gradients and influence advective flow include: barometric pressure, rise and fall in water table, wind fluctuations, and rainfall percolation (Tyler et al., 1986).

Gas movement in the unsaturated zone, either through advection or diffusion, is governed by the properties of the porous media (soil type, moisture content, tortuosity, and air permeability), the amount of gas or pressure generated by the given source and the specific properties of the diffusing gas.

Gas-phase transport at the Area 5 RWMS will most likely be limited to diffusion. Nonetheless, there is some evidence that barometric pumping may play a role in moving gases in fractured rocks and its importance in alluvium is yet unknown. Studies are now underway at the Area 5 RWMS to determine the importance of advective barometric pumping in gas transport (Hammermeister, 1994).

\section{Diffusional Soil-Gas Transport}

The porous medium affects diffusion in several ways. Soil pores will vary in size, shape, and tortuosity. Coarse-textured soils tend to be less porous than fine-textured soils, even though the mean size of the individual pores is greater in the former (Hillel, 1982). The smaller the soil particles, the smaller the effective diffusion coefficient will be. Generally, as the bulk density increases, porosity decreases causing diffusion to decrease (Dragun, 1988).

Increasing soil moisture decreases soil gas diffusion by reducing the cross-sectional area where diffusion can occur and by reducing the surface area available for adsorption when the given gas solubility in water is low. The rate of diffusion of nonionized, nonpolar solutes in water held in a matrix is directly proportional to the volumetric water content. Diffusion rates for ions and charged molecules are more complicated but still are sensitive to volumetric water content and, in turn, to matric potential (Griffin, 1981). Organic matter and clay mineral content significantly influence diffusion in soils by increasing sorption of the chemical onto the surfaces of soil particles (Dragun, 1988).

The specific properties of the diffusing gas will determine how the chemical will behave (or react) in the porous media. The molecular structure of the chemical will determine the nature of the intermolecular forces (bonding mechanisms). For example, van der Waals forces and dipole-dipole interactions are relatively week intermolecular forces that affect diffusion and volatilization of organic molecules and uncharged inorganic molecules in soils. (Yaron, 1989; Dragun, 1988). The chemical structure also determines the molecular weight, which is directly linked to the diffusion coefficient of the chemical (Dragun, 1988). 


\section{CONCLUSIONS}

The Area 5 RWMS soil under the prevailing current conditions can potentially provide an effective barrier to the movement of a number of organic and inorganic contaminants. However, to make accurate and reliable estimates concerning sorption of hazardous and radioactive wastes beneath the waste repositories at the Area 5 RWMS, it would be necessary to conduct sorption studies with soils directly underlying the RWMS. It is also suggested that the experimental conditions resemble field or "real" conditions as much as possible. Column experiments would be able to better resemble unsaturated conditions. The soil solution concentrations could also be adjusted so that they parallel or mimic field conditions much better.

No specific information regarding biological processes at the Area 5 RWMS was found. Under harsh, arid conditions, long periods of dryness may minimize the importance of biotic interactions and the low organic matter content, even at the surface, maximize the role of the mineral fraction in the abiotic interactions. Nonetheless, without knowing the microbial numbers, distribution and activities at the site, it is difficult to assess the role of biodegradation on the fate of the waste at the repository. At least some preliminary studies should be conducted to evaluate the microbial communities within the soils at the Area 5 RWMS that would give insight and help determine the relative potential of that ecosystem for any biochemical cycling. It should be kept in mind that not only the knowledge of the qualitative and quantitative aspects of the microbiology of the ecosystem should be addressed but also the activities of the microorganisms should be investigated. If the microbial ecology at the Area 5 RWMS is investigated, it would also be best to compare microbial population characteristics from a site close to waste already in place and a site further away to see whether or not any changes (acclimation or adaptation) have occurred.

Gas transport is the most likely transport mechanism at the Area 5 RWMS. Mobility of hazardous constituents in the gas phase at the Area 5 RWMS is being investigated by REECo, Special Projects Section. Since gas flow is expected to be the dominant operating transport mechanism at the site and given that specific studies addressing the attenuation of organics in these soils have only been partially investigated, it is critical to emphasize the importance of evaluating the fate and transport processes of VOCs at the Area 5 RWMS. 


\section{REFERENCES}

Andraski, B.J. 1992. Water movement through soil as a low-level radioactive-waste site in the Amargosa Desert. In: USGS Yearbook, Fiscal Year 1991. U.S. Geol. Survey, Denver, CO., pp. 73-75.

Atlas, R.M and R. Bartha. 1987. Microbial Ecology; Fundamentals and Applications. Second Edition. The Benjamin/Cummings Publishing Co. Inc., Menlo Park, California.

Adamson, A.W. 1982. Physical chemistry of surfaces. 4th. ed., John Wiley and Sons, Inc., New York, 1982.

Bailey, G.W. and J.L. White. 1964. Review of adsorption and desorption of organic pesticides by soil colloids, with implications concerning pesticide bioactivity. J. Agr. Food Chem. 12:324.

Bailey, G.W. and J.L. White. 1970. Factors influencing the adsorption, desorption and movement of pesticides in soil. Residue Rev. 32:29-92.

Ball, W.P. and P.V. Robert. 1991. Long-term sorption of halogenated organic chemicals by aquifer material. 1. Equilibrium. Environ. Sci. Technol. 25:1223-1237.

Bohn, H.L., B.L. McNeal and G.A. O'Connor. 1985. Soil Chemistry. 2nd. Ed., John Wiley \& Sons, Inc., New York.

Brock, T.D. and M.T. Madrigan. 1991. Biology of microorganisms. sixth edition. Prentice Hall, Englewood Cliffs, New Jersey.

Case, C.M., J.O. Davis, J.C. Heidker and M.R. Whitbeck. 1992. Studies of infiltration and lead-soil interactions at the radioactive waste management site in Area 5 of the Nevada Test Site. Water Resources Center, Desert Research Institute, University and Community College System of Nevada, Reno, DOE/NV/10384-13. Pub. No. 45054.

Case, C.M., J. Davis, R. French and S. Raker. 1984. Site characterization in connection with the low level defense waste management site in Area 5 of the Nevada Test Site, Nye County, Nevada Final Report. Water Resources Center, Desert Research Institute, University and Community College System of Nevada, Reno, DOE/NV/10162-13. Pub. No. 45034.

Cheng, H.H. and W.C. Koskinen. 1986. Processes and factors affecting transport of pesticides to groundwater. p. 12-14. In: W.Y. Gardner, R.C. Honeycutt and H.N. Nigg. Evaluation of pesticides in groundwater. ACS Symposium Series \#315. American Chemical Society, Washington, D.C.

Chiou, C.T. and T.D. Shoup. 1985. Soil sorption of organic vapors and effects of humidity on sorptive mechanism and capacity. Environmental Science and Technology. 19:1196-1200.

Conrad, S.H., S.W. Tyler and J.B. Chapman. 1993. Inferring paleo-recharge using several naturally occurring tracers taken from a thick alluvial vadose zone at the Nevada Test Site. American Geophysical Union Fall Meeting, 1993, San Francisco, California. 
Culver, T.B., C.A. Shoemaker and L.W. Lion. 1991. Impact of vapor sorption of the subsurface transport of volatile organic compounds; numerical model and analysis. Water Resources Research. 27:2259-2270.

Curtis, G.P., M.Reinhard and P.V. Roberts. 1986. Sorption of hydrophobic organic compounds by sediments. In: J.A. Davis and K.F. Hayes (eds.). Geochemical processes at mineral surfaces: an overview. ACS Symposium Series, No. 323. American Chemical Societyk, Washington D.C., 683.

Daniels, W.R. and J.L. Thompson. 1983. Laboratory and field studies related to the radionuclide migration project. Los Alamos National Laboratory, Los Alamos, New Mexico. LA-10121-PR.

Detty T.E., J. Chapman and S.W. Tyler. 1993. Water fluxes in a deep arid-region vadose zone. American Geophysical Union, Fall Meeting 1993, San Francisco, California. p. 297.

Devinny, J.S., L.G. Everett, J.C.S. Lu and R.L. Stollar. 1990. Subsurface Migration of Hazardous Wastes. Environmental Engineering Series. Van Nostrand Reinhold, New York.

Dozier, B.L. and S.E. Rawlinson. 1991. Conceptual model for the geology in Area 5. DOE/NV/10630-14.

Dragun, J. 1988. The Soil Chemistry of Hazardous Materials. Hazardous Materials Control Research Institute. Silver Springs, Maryland.

EG\&G/SAIC. 1991. Radiological performance assessment for the Area 5 Radioactive Waste Management Site at the Nevada Test Site. EG\&G Idaho, Inc. and Science Applications International Corporation (SAIC), Idaho Falls.

Elwan, S.H. and A. Diab. 1970. Studies on desert microbiology. V. Certain patterns of bacterial development in relation to depth and environment, U.A.R.J. Bot. 13:171-179.

Estrella, M.R., M.L. Brusseau, R.S. Maier, I.L. Pepper, P.J. Wierenga and R.M. Miller. 1992. Biodegradation, sorption and transport of 2,4-Dichlorophenoxyacetic acid in saturated and unsaturated soils. Applied and Environmental Microbiology. Vol. 59, No. 12, pp. 4266-4273.

Estrella, R., S. Tyler, J. Chapman and M. Miller. 1993. Area 5 site characterization project - report of hydraulic property analysis through August 1993. Water Resources Center, Desert Research Institute, Publication \# 45121.

Focht, D.D. and J.P. Martin. 1979. Microbial and biochemical aspects of semiarid agricultural soils. In A.E. Hall, G.H. Cannell and H.W. Lawton (eds.). Agriculture in Semi-Arid Environments. Springer-Verlag, Berlin.

Freeze, R.A. and J.A. Cherry. 1979. Groundwater. Prentice-Hall, Inc., Englewood Ciffs, N.J.

Friedmann, E.I. and R. Ocampo. 1976. Endolithic blue-green algae in the dry valleys: primary producers in the Antarctic ecosystem. Science, 193:1247-1249 
Friedmann, E.I. and R. Ocampo-Friedmann. 1984. Endolithic microorganisms in extreme dry environments: analysis of a lithobiotic microbial habitat. In: M.J. Klug and C.A. Reddy (eds.). Current Perspectives in Microbial Ecology. American Society for Microbiology, Washington, D.C., pp. 177-185.

Gee, G.W., P.J. Wierenga, B.J. Andraski, M.H. Young, M.J. Fayer and M.L. Rockhold. 1994. Variations in Water Balance and Recharge Potential at Three Western Desert Sites. Soil Science Society of America Journal. 58:64-72.

Glass, D.J. 1991. Waste management: biological treatment of hazardous wastes. Environment. Vol. 33 , No. 9 , p.5

Green, R.E., J.M. Davidson and J.W. Biggar. 1980. An assessment of methods for determining adsorption-desorption of organic chemicals. In: A. Banin and U. Kafkafi (eds.). Agrochemicals in soils. Israel Society of Soil Science, Pergamon Press, New York.

Griffin, D.M. 1981. Water and Microbial Stress. Advances in Microbial Ecology. 5:91-136.

Hance, R.J. 1965. Observations on the relationship between the adsorption of diuron and the nature of the adsorbent. Weed Research, 5:108.

Hance, R.J. 1977. The adsorption of atraton and monuron by soils at different water contents. Weed Research, 17:197-201.

Hammermeister, D. 1994. Personal communication. Reynolds Electrical \& Engineering Company, Special Projects Section, Las Vegas, Nevada.

Hayes, K.F. and J.O. Leckie. 1987. Modeling ionic strengtn effects on cation adsorption at hydrous oxide/solution interfaces. J. Colloid Interface Sci., 115:564.

Hayes, K.F., C. Papelis and J.O. Leckie. 1988. Modeling ionic strength effects on anion adsorption at hydrous oxide/solution interfaces. J. Colloid Interface Sci., 125:717-726.

Hillel, D. 1982. Introduction to Soil Physics. Academic Press, Inc. New York, NY.

Houston, S.L, D.K Kreamer and R. Marwing. 1989. A batch-type testing method for determination of adsorption of gaseous compounds on partially saturated soils. Geotechnical Testing Journal, GTJOD, vol. 12, No. 1, March 1989, pp. 3-10.

Hurle K. and Walker A. 1980. Persistance and its prediction. In: Hance RJ (ed) Interactions between herbicides and the soil. Academic Press, New York London, pp 83-122.

Hutchinson, I.P.G. and R.D. Ellison. 1992. Attenuation of chemicals constituents. In: Hutchinson, I.P.G. and R.D. Ellison (ed.), Mine Waste Management. Lewis Publishers. Boca Raton. pp. 204-268.

Jones, B.F. 1982. Mineralogy of fine grained alluvium from borehole U11G, Expl. 1, Northern Frenchman Flat Area, Nevada Test Site. U.S. Geological Survey, Open-File Report 82-765. 
Jury, W.A. 1986. Adsorption of organic chemicals onto soils. p.177-189. In: Vadose Zone Modeling of Organic Pollutants. (ed.). Academic Press, New York, N.Y.

Karickhoff, S.W., 1984. Organic pollutant sorption in aquatic systems. J. of Hydrau. Engineer., 110:707-735.

Kaufman, W.J. 1963. An appraisal of the distribution coefficient for estimating underground movement of radioisotopes. Hazleton-Nuclear Science Corporation, Palo Alto, California.

Kautsky, M. 1984. Sorption of cesium and strontium by arid region desert soil. Water Resources Center, Desert Research Institute, University and Community College System of Nevada, Reno, DOE/NV/10162-16. Pub. No. 45037.

Knox, R.C., D.A. Sabatini and L.W. Canter. 1993. Subsurface Transport and Fate Processes. Lewis Publishers. Boca Raton, Florida.

Macalady, D.L. and Wolfe, N.L. 1985. Effects of sediments sorption and abiotic hydrolyses. I: Organo-phosphorothioate esters. J Agric Food Chem 33:167-173.

Mills, A.C. and J.W. Biggar. 1969. Solubility-temperature effect on the adsorption of Gamma and Beta BHC from aqueous and hexane solution by soil material. Soil Sci. Soc. Am. Proc. 33:210-216.

Mingelgrin, U. and R. Prost. 1989. Surface Interactions of Toxic Organic Chemicals with Minerals. In: Z. Gerstl, Y. Chen, U. Mingelgrin and B. Yaron (eds.). Toxic Organic Chemicals in Porous Media. Springer-Verlag, New York.

Ogram, A.V., R.E. Jessup, L.T. Ou and P.S.C. Rao. 1985. Effect of sorption on biological degradation rates of 2,4-Diclorophenoxy acetic acid in soils. Appl. Environ. Microbiol. 49:582-587.

Pennel, K.D., R.D. Rhue, P.S.C. Rao and C.T. Johnston. 1992. Vapor-phase sorption of p-Xylene and water on soils and clay minerals. Environmental Science and Technology. 26:756-763.

Peterson, M.S., L.W. Lion and C.A. Shoemaker. 1988. Influence of vapor phase sorption and diffusion of the fate of trichloroethylene in an unsaturated aquifer system. Environmental Science and Technology. 22:571-578.

Piwoni, M.D. and J.W. Keeley. 1990. Basic concepts of contaminant sorption at hazardous waste sites. U.S. Environmental Protection Agency, EPA/540/4-90/053.

Rao, P.S.C. and J.M. Davison. 1980. Estimation of pesticide retention and transformation parameters required in nonpoint source pollution models. pp. 23-67. In: M.R. Overcash and J.M. Davison. Environmental Impact of Nonpoint Source Pollution. Ann Arbor Sci. Publ. Co., Ann Arbor, MI.

Reynolds Electrical \& Engineering Co. 1993a. Hydrogeologic Data for Science Trench Boreholes at the Area 5 Radioactive Waste Management Site, Nevada Test Site, Nye County, Nevada. Special 
Project Section, Environmental Management Division, Reynolds Electrical \& Engineering Co., Inc., Las Vegas, NV.

Reynolds Electrical \& Engineering Co. 1993b. Site Characterization and Monitoring Data from Area 5 Pilot Wells, Nevada Test Site, Nye County, Nevada. Special Project Section, Environmental Management Division, Reynolds Electrical \& Enginnering Co., Inc., Las Vegas, NV.

Reynolds Electrical \& Engineering Co. 1993c. 1993 Annual Neutron Logging Report for Pit 3.

Romney, E.M., V.Q. Hale, A. Wallace, O.R. Lunt, J.D. Childress, H. Kaaz, G.V. Alexander, J.E. Kinnear and T.L. Ackerman. 1973. Some characteristics of soil and perennial vegetation in northern Mohave desert areas of the Nevada Test Site, University of California Laboratory of Nuclear Medicine and Radiation Biology, UCLA \#12-916, 340p.

Rychert, R.C., J. Skujins, D. Sorensen and D. Porcella. 1978. Nitrogen fixation by lichens and free-living microorganisms in desert. In: Nitrogen in Desert Ecosystems (N.E. West and J. Skujins, eds.), pp. 20-30, Dowden, Hutchinson and Ross, Stroudsburg, Pennsylvania.

Scanlon, B.R. 1992. Evaluation of liquid and vapor water flow in desert soils based on chlorine 36 and tritium tracers and nonisothermal flow simulations. Water Resources Research, Vol. 28, No. 1, pp. 285-297.

Schmeltzer, J.S. 1993. Effects of soil moisture, soil carbonate and organic matter content on vapor phase adsorption of volatile organic compounds using inverse gas chromatography. M.S. Thesis, Department of Geoscience, University of Nevada, Las Vegas.

Scrow, K.M. 1982. Rate of biodegradation. In: W.J. Lyman, W.F. Reehl and D.H. Rosenblatt (eds.), Handbook of Chemical Property Estimation Methods. McGraw-Hill Co., New York.

Singer, M.J. and D.N. Munns. 1987. Soils: An Introduction. Macmillan Publishing Co., New York, New York.

Skujins, J. 1984. Microbial ecology of desert soils. Advances in Microbial Ecology. 7:49-91.

Speitel, G.E., C.J. Lu, M. Turakhia and X.J. Shu. 1989. Biodegradation of trace concentration of substituted phenols in granular activated carbon columns. Environ. Sci. Technol. 23:68-74.

Steinberg, S.M. and D.K. Kreamer. 1993. Evaluation of the sorption of volatile organic compounds by unsaturated calcareous soils from southern Nevada using inverse gas chromatography. Environmental Science \& Technology. Vol. 27, No. 5, pp. 883-888.

Stumm, W. 1992. Chemistry of the solid-water interface. John Wiley \& Sons, New York, 428 pp.

Sutton, P.A. and J.F. Barker. 1985. Migration and attenuation of selected organics in a sandy aquifera natural gradient experiment. Ground Water, Vol. 23, No. 1, pp. 10-16.

Thomas, J.M. and C.H. Ward. 1992. Subsurface microbial ecology and bioremediation. Journal of Hazardous Materials, 32:179-194. 
Torstensson, L. 1988. Outlook Agric. 17:120-124.

Tyler, S.W., M.R. Whitbeck, M.W. Kiek, J.W. Hess, L.G. Everett D.K. Kreamer and B.H. Wilson. 1986. Processes affecting subsurface transport of leaking underground tank fluids. Water Resources Center, Desert Research Institute, University of Nevada System, Reno, Nevada. Pub. No. 41100.

U.S. Department of Agriculture. 1954. Diagnosis and improvement of saline and alkali soils, Agriculture Handbook No. 60.

Valsaraj, K.T. and L.J. Thibodeaux. 1988. J. Hazard. Mater. 19:79.

Weber, W.J., P.M. McGinley and L.E. Katz. 1991. Sorption phenomena in subsurface systems: concepts, models and effects on contaminant fate and transport. Water Resources Research, Vol. 25, No. 5, pp. 499-528.

White, D.C. 1983. Analysis of microorganisms in terms of quantity and activity in natural environments. In: J.H. Slater, R. Whittenbury and J.W.T. Wimpenny. Microbes in Their Natural Environments: Thirty-fourth symposium of the Society for General Microbiology. Cambridge, New York.

Wobber, F.J. 1990. Subsurface microbiological research at the United States Department of Energy, In: C.B. Fliermans and T.C. Hazen (eds.), Proc. of the 1st. Int. Symp. of Microbiology of the Deep Subsurface, January 15-19, 1990. Orlando, FL. WSRC Information Services, Aiken, SC, 1990, pp. 1-4.

Wolfsberg, K. 1979. Sorption-desorption studies of Nevada Test Site alluvium and leaching studies of nuclear test debris. Los Almos Scientific Laboratory, Los Alamos, New Mexico. LA-7216-MS.

Yardon, B., P. Sutherland, T. Galin and A.J. Acher. 1989. Soil pollution by petroleum products, II: adsorption-desorption of "kerosene" vapors on soils. Journal of Contaminant Hydrology, 4:347-358.

Yaron, B. 1989. General principles of pesticide movement to groundwater. Agriculture, Ecosystems and Environment. 26:275-297.

Yaron, B. and S. Saltzman. 1977. Influence of water and temperature on adsorption of Parathion by soils. Soil Sci. Soc. Am. Proc. 36:583-586.

Yaron, B., Z. Gerstl and W.F. Spencer. 1985. Behavior of herbicides in irrigated soils. pp.121-217. In: Stewart, B.A. (ed.). Advances in Soil Science. Vol. 3. Springer-Verlag, N.Y. 


\section{DISTRIBUTION}

\section{Desert Research Institute}

Roger Jacobson

Desert Research Institute

Water Resources Center

P.O. Box 19040

Las Vegas, NV 89132-0040

Marjory Jones

Desert Research Institute

Water Resources Center

P.O. Box 60220

Reno, NV 89506-0220

\section{International Technology Corp.}

Rick Waddell

Geotrans, c/o IT

4330 Valley View

Suite 112, MS-439

Las Vegas, NV 89103

Joe Yeasted

International Technology Corporation

4330 S. Valley View

Suite 114

Las Vegas, NV 89103

\section{Lawrence Livermore National Laboratory}

Lee Davisson

Nuclear Chemistry Division

Lawrence Livermore National Laboratory

P.O. Box 808

L-237

Livermore, CA 94550

Greg Nimz

Earth Sciences Division

Lawrence Livermore National Laboratory

P.O. Box 808, MS L207

Livermore, CA 94550

\section{Los Alamos National Laboratory}

Joe Thompson

Los Alamos National Laboratory

INC-11, MS J514

P.O. Box 1663

Los Alamos, NM 87545

\section{Raytheon Services Nevada}

Stuart E. Rawlinson

Raytheon Services Nevada

P.O. Box 95487, M/S 580

Las Vegas, NV 89193-5487

Reynolds Electrical \& Engineering Co.

Martha DeMarre

Chief, Document Research Section

Health Protection Dept.

Reynolds Electrical \& Engineering Co.

P.O. Box 98521

Las Vegas, NV 89193-8521

Brian Dozier

Reynolds Electrical \& Engineering Co.

2501 Wyandotte

Mercury, NV 89102

Kent Johnejack

Reynolds Electrical \& Engineering Co.

P.O. Box 98521

Las Vegas, NV 89193-8521

Michael J. Sully

Reynolds Electrical \& Engineering Co.

P.O. Box 98521 , M/S 966

Las Vegas, NV 89193-8521

\section{Sandia National Laboratories}

John Cochran

GCD Project Leader

Sandia National Laboratories

P.O. Box 5800,

Albuquerque, NM 87185-1345

David Gallegos

Sandia National Laboratories

Department 6331

P.O. Box 5800, M/S 1345

Albuquerque, NM 87185-1345 


\section{State of Nevada}

Larry Franks

Nevada State Health Department

Radiological Health Section

620 Belrose Avenue

Las Vegas, NV 89158

\section{U.S. Department of Defense}

David Bedsun

Defense Nuclear Agency

Field Command

Nevada Operations Office

P.O. Box 208

Mercury, NV 89023-0208

\section{U.S. Department of Energy}

Gylan Allen, Director

Test Operations Division

Nevada Operations Office

U.S. Department of Energy

P.O. Box 98518

Las Vegas, NV 89193-8518

Warren D. Black

U.S. Department of Energy

EM-322, Trevion II Bldg.

1000 Independence Avenue SW

Washington, D.C. 20585

Joanne M. Bradbery, Director

Contracts Division

Nevada Operations Office

U.S. Department of Energy

P.O. Box 98518

Las Vegas, NV 89193-8518

Doug Duncan

Hydrology Program Manager

Office of Environmental Restoration

and Waste Management

Nevada Operations Office

U.S. Department of Energy

P.O. Box 98518

Las Vegas, NV 89193-8518
Donald Elle, Director

Environmental Protection Division

Nevada Operations Office

U.S. Department of Energy

P.O. Box 98518

Las Vegas, NV 89193-8518

Joseph N. Fiore, Acting Assistant Manager

Office of Environmental Restoration

and Waste Management

Nevada Operations Office

U.S. Department of Energy

P.O. Box 98518

Las Vegas, NV 89193-8518

Carl P. Gertz, Director

Waste Management Division

Nevada Operations Office

U.S. Department of Energy

P.O. Box 98518

Las Vegas, NV 89193-8518

Joseph M. Ginanni

Waste Management Division

Nevada Operations Office

U.S. Department of Energy

P.O. Box 98518

Las Vegas, NV 89193-8518

Joseph H. Kitchen

Project Control and Technology

Development Division

Nevada Operations Office

U.S. Department of Energy

P.O. Box 98518

Las Vegas, NV 89193-8518

Steve Lawrence

Environmental Restoration Division

Nevada Operations Office

U.S. Department of Energy

P.O. Box 98518

Las Vegas, NV 89193-8518

John S. Ledbetter

Contracts Division

Nevada Operations Office

U.S. Department of Energy

P.O. Box 98518

Las Vegas, NV 89193-8518 
Steve Leedom

Test Operations Division

Nevada Operations Office

U.S. Department of Energy

P.O. Box 98518

Las Vegas, NV 89193-8518

Steve Mellington, Director

Environmental Restoration Division

Nevada Operations Office

U.S. Department of Energy

P.O. Box 98518

Las Vegas, NV 89193-8518

Beth Moore

Waste Management Division

Nevada Operations Office

U.S. Department of Energy

P.O. Box 98518

Las Vegas, NV 89193-8518

Richard Pearl

Environmental Protection Division

Nevada Operations Office

U.S. Department of Energy

P.O. Box 98518

Las Vegas, NV 89193-8518

\section{U.S. Geological Survey}

Virginia Glanzman

U.S. Geological Survey

Box 2506, MS 913

Denver Federal Center

Denver, CO 80225

Randy Laczniak

U.S. Geological Survey

Water Resources Division

6770 S. Paradise Rd.

Las Vegas, NV 89119

Paul Orkild

U.S. Geological Survey

Box 2506, MS 913

Denver Federal Center

Denver, CO 80225
Doug Trudeau

U.S. Geological Survey

Water Resources Division

6770 S. Paradise Rd.

Las Vegas, NV 89119

\section{LIBRARIES}

Annie Kelley

State Documents Department

Nevada State Library

Capitol Complex

Carson City, NV 89710

Archives

Getchell Library

University of Nevada, Reno

Beverly Carter

MacKay School of Mines Library

University of Nevada, Reno

Document Section, Library

University of Nevada, Las Vegas

4505 Maryland Parkway

Las Vegas, NV 89154

Library (Stead)

Desert Research Institute

P.O. Box 60220

Reno, Nevada 89506-0220

Library

IT Corporation

$4330 \mathrm{~S}$. Valley View

Suite 114

Las Vegas, NV 89103

ATTN: Toni Miller

Library

Southern Nevada Science Center

Desert Research Institute

P.O. Box 19040

Las Vegas, NV 89132-0040

Technical Information Resource Center

Nevada Operations Office

U.S. Department of Energy

P.O. Box 98518

Las Vegas, NV 89193-8518 
Water Resources Research Archives

University of California

Room 40, North Gate Hall

Berkeley, CA 94720 